\title{
Development of portable knapsack power weeder
}

\author{
B. Devojee, S. S. Meena, A. K. Sharma and C. Agargwal
}

Received : 11.11.2017; Revised : 05.02.2018; Accepted : 14.02.2018

See end of the Paper for authors' affiliation

Correspondence to :

B. Devojee

Department of Farm Machinery and Power Engineering, College of Technology and Engineering, Udaipur (Rajasthan) India Email : devojibhookya@ gmail.com
- ABSTRACT : Weed management is an ever-present challenge to crop production. Presence of weeds in general reduces crop yield by 31.5 per cent $(22.7 \%$ in Rabi season and 36.5 per cent in Kharif and summer season). Yield losses due to weeds were about 65 per cent depending on the crop, degree of weed infestation, weed species and management practices. Presently available weeder mostly run by tractor or power tiller, these are large in size, cannot work for low inter row spaced crops.To over come these problems, portable knapsack power weeder was developed for low inter row spaced crops with width of cut was $25 \mathrm{~cm}$. The main working components of power weeder were flexible drive shaft, worm gear box, rotor shaft, flanges and blades. The" L" type blade was selected having length, width and thickness of $130 \mathrm{~mm}, 30 \mathrm{~mm}$ and $5 \mathrm{~mm}$, respectively, operating with a rotor shaft of $20 \mathrm{~mm}$ in diameter. Maize and chilli was tested with number of blades per flange (2, 4 and 6$)$.

- KEY WORDS : Engine, Flexible drive shaft, Worm gear box, Rotor shaft, Flanges, Blades

-HOW TO CITE THIS PAPER : Devojee, B., Meena, S.S., Sharma, A.K. and Agargwal, C. (2018). Development of portable knapsack power weeder. Internat. J. Agric. Engg., 11(1) : 35-40, DOI: 10.15740/HAS/IJAE/11.1/35-40. 